\title{
VARIATION IN DROSERA PYGMAEA
}

\section{Robert Gibson • 5 Kristen Close • Cardiff Heights • NSW 2285 • Australia • robert.gibson@, environment.nsw.gov.au}

Keywords: Drosera pygmaea, variation.

\author{
Introduction
}

Drosera pygmaea DC. grows naturally across wetter parts of southern Australia and also occurs in New Zealand (Lowrie 1989; Salmon 2001), making it the most widespread of all pygmy sundews. It is aptly named thanks to its small size which makes it easy to overlook and challenging to study. However the effort to study this species has revealed some interesting morphological variation which is discussed here.

\section{Typical Plants}

Drosera pygmaea plants are typically 10 to $15 \mathrm{~mm}$ across when mature and have short, erect single-flowered scapes with flowers with four sepals, four white petals and four stamens. The flowers remain erect in fruit. The leaves have filiform petioles which are usually olive green to red and orbicular lamina, with a peltate attachment to the petiole which also may be olive green or red. The elongated silvery white stipules for a prominent conical bud that protects the new growth from desiccation and usually opens in April to July when gemmae are produced.

\section{Variation in Pigmentation}

Golden green plants are known from a few populations, notably in the Little Desert and at Lake Kai Iwi in the North Island of New Zealand (Salmon 2001). These plants dominate at both locations and have red glands in their insect-trapping hairs which demonstrate that they are not albinos (Fig. 1).

The petals of D. pygmaea are usually pure white with a translucent broad trilobed mid-vein at the base. However, in some populations, such as near Queenstown in Western Tasmania (Gibson 1998), Mulgoa, New South Wales and Lake Ohia in New Zealand in the mid-vein has red pigment. In some cases the same bicolored effect is produced by red pigment from the inner surfaces of the sepals showing through the translucent mid-vein of the petals; in both cases to produce the color contrast pattern found in several other pygmy sundews that is likely to play a role in influencing insect behavior so they may more effectively cross-pollinate these flowers.

\section{Variation in Flower Part Numbers and Number of Flowers per Scape}

The vast majority of flowering plants of D. pygmaea I have seen across its range have the typical four-merous radial symmetry of the flowers. However, plants with five-merous flowers occur sporadically in wild populations and in cultivated plants. I was made first aware of this by a photo published on page 65 of Kondo and Kondo (1983: see the flower on the far-right of their photo).

Drosera pygmaea plants rarely also produce scapes that may have up to seven flowers in a onesided raceme. In this case the pedicels are up 2 to $3 \mathrm{~mm}$ long and the flowers remain erect in 


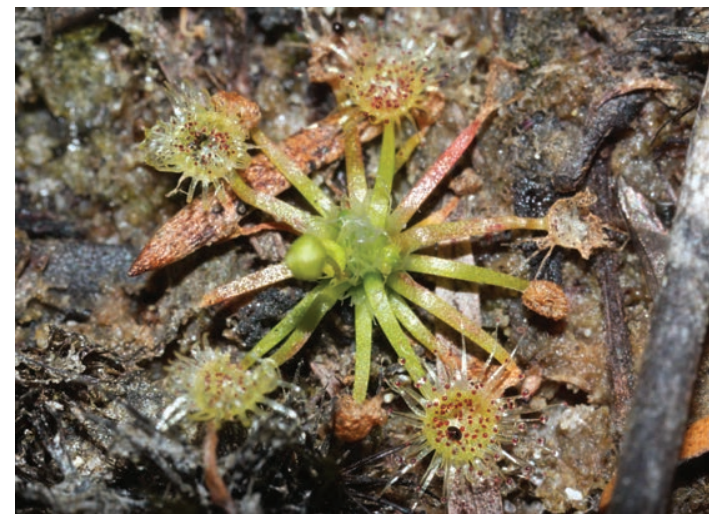

Figure 1: Yellow-green plant of Drosera pygmaea in scape at Lake Kai Iwi, North Island, New Zealand. Note the presence of red pigment in the gland of the insect-trapping hairs that show that this is not an albino.

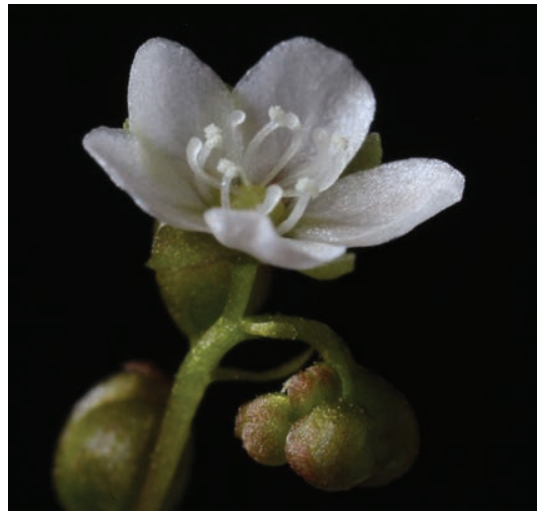

Figure 2: Atypical five-merous flower of $D$. pygmaea on an even rarer multiflowered scape. The white (rather than yellow) anthers and pollen most readily distinguish this plant from being $D$. occidentalis subsp. australis.

fruit. Sometimes some of the flowers in this inflorescence are also five-merous (Fig. 2). I have observed such plants near Gosford and in the Blue Mountains in New South Wales and in South East Queensland. They bear strong resemblance to plants of $D$. occidentalis subsp. australis from South Western Australia (Lowrie 1989), but can be readily distinguished by anther and pollen color and the degree of stipule division. In all cases these D. pygmaea plants with anomalous flowers and scapes predominantly produce one-flowered scapes of four-merous flowers which indicate that these anomalies are temporary, perhaps caused by errors in cell division.

\section{Conclusions}

Drosera pygmaea is a small and widespread sundew that is commonly overlooked and difficult to study due to its small size and brief flowering period. However in its range are some unusual variants, some of which are fleeting in nature.

Acknowledgements: Thanks to Richard Davion for initial discussions about morphological variation in this species and also to Greg Bourke, Andrew Broome, Kirk 'Füzzy' Hirsch, Paul Lander, Bruce Pierson, Brian Quinn, Bruce Salmon, and Peter Sebborn for assistance with fieldwork in which I have been able to observe this species in many parts of its range.

\section{References:}

Gibson, R. 1998. Observations on a selection of Tasmanian carnivorous plants. Carnivorous Plant Newsletter 27(3): 90-92.

Kondo, K., and Kondo, M. 1983. Carnivorous Plants of the World in Color. Ienohikari Association, Tokyo.

Lowrie, A. 1989. Carnivorous Plants of Australia: Volume 2. University of Western Australia Press, Nedlands.

Salmon, B. 2001. Carnivorous Plants of New Zealand. Ecosphere Publications, Auckland. 